\title{
Synthesis, Spectroscopic, and Antimicrobial Studies of the Bivalent Nickel, and Copper Complexes of Thiosemicarbazide
}

\author{
Shikha PARMAR* and Yatendra KUMAR \\ I. T. S. Paramedical College (Pharmacy); Delhi Meerut Road, Muradnagar, Ghaziabad 201206, India.
}

Received October 1, 2008; accepted March 11, 2009; published online March 16, 2009

\begin{abstract}
A series of metal complexes of $\mathrm{Ni}(\mathrm{II})$, and $\mathrm{Cu}(\mathrm{II})$ having the general composition $\left[\mathrm{M}(\mathrm{L})_{2} \mathrm{X}_{2}\right]$ with thiosemicarbazide have been prepared and characterized by elemental chemical analysis, molar conductance, magnetic susceptibility measurements, mass, IR, electron paramagnetic resonance, and electronic spectral studies. The IR spectral data suggest the involvement of sulfur and terminal amino nitrogen in coordination to the central metal ion. On the basis of spectral studies, an octahedral geometry has been assigned for the $\mathrm{Ni}$ (II) complexes whereas tetragonal geometry for $\mathrm{Cu}$ (II) complexes. Thiosemicarbazide and its metal complexes have been tested in vitro against a number of microorganisms in order to assess their antimicrobial properties.
\end{abstract}

Key words thiosemicarbazide; nickel(II); copper(II); antibacterial activity; antifungal activity

Sulfur compounds have been the subject of interest in coordination chemistry. Thiosemicarbazide-based compounds have been extensively studied over the last couple of decades. ${ }^{1-3)}$ The various schiff bases of thiosemicarbazide (thiosemicarbazones) have attracted much attention because of the large number of potentially useful biological properties such as antibacterial, antifungal, antitumor, antimalarial, antiviral, radioprotective, trypanocidal and anti-inflammatory activities. ${ }^{4-15)}$ Their activity has frequently been thought to be due to their ability to chelate metals. It is well known that the compounds containing $>\mathrm{C}=\mathrm{S}$ moiety have a strong ability to form metal complexes. Although many structures of thiosemicarbazone complexes have been reported, there are a few for complexes of the precursor thiosemicarbazide. ${ }^{16)}$ Thiosemicarbazide usually acts as a chelating ligand for transition metal ions by bonding through the sulfur and terminal amino nitrogen atom, although in some cases they behave as monodentate ligands where bond through sulfur only. ${ }^{17}$ )

It is interesting to note that in the literature reported, $\mathrm{Ni}$ (II) and $\mathrm{Cu}(\mathrm{II})$ complexes of thiosemicarbazide reflect higher tendency to exhibit square planar geometry. ${ }^{18)}$ A variety of colored compounds containing thiosemicarbazide can be obtained depending on the method of preparation and also on the anion used. ${ }^{199}$ The control of the geometry around a metal ion is important for controlling the properties of a compound. Although $\mathrm{Ni}(\mathrm{II})$ and $\mathrm{Cu}(\mathrm{II})$ complexes of thiosemicarbazide are reported in literature, ${ }^{20-22)}$ antimicrobial properties of these complexes are not adequately reported. Thus, it was considered desirable to study the structure of $\mathrm{Ni}(\mathrm{II})$ and $\mathrm{Cu}(\mathrm{II})$ thiosemicarbazide metal complexes to evaluate their tendency to exhibit antimicrobial properties.

In view of the above applications, in this paper we report the synthesis, spectroscopic, and antimicrobial studies of the $\mathrm{Ni}(\mathrm{II})$ and $\mathrm{Cu}(\mathrm{II})$ complexes of thiosemicarbazide.

Instrumentation and Materials The $\mathrm{C}, \mathrm{H}$, and $\mathrm{N}$ were analyzed on a Carlo-Erba 1106 elemental analyzer. The nitrogen content of the complexes was determined using Kjeldahl's method. Molar conductance was measured with the ELICO (CM82T) conductivity bridge. Magnetic susceptibilities were measured at room temperature on a Gouy balance using $\mathrm{CuSO}_{4} \cdot 5 \mathrm{H}_{2} \mathrm{O}$ as callibrant. Diamagnetic corrections were made using Pascal's constants. The electronic impact mass spectrum was recorded on a JEOL, JMS-DX303 mass spectrometer. IR spectra $(\mathrm{KBr})$ were recorded on a FTIR spectrum
}

BX-II spectrophotometer. The electronic spectra were recorded in dimethyl sulfoxide (DMSO) on a Shimadzu UV mini-1240 spectrophotometer. The electron paramagnetic resonance (EPR) spectra of the complexes were recorded as polycrystalline sample, at room temperature for $\mathrm{Cu}(\mathrm{II}) \mathrm{com}$ plexes on a $\mathrm{E}_{4}$-EPR spectrometer using the 1,1-diphenyl-2-picrylhydrazyl (DPPH) as the g-marker. The molecular weights of the complexes were determined cryoscopically in benzene.

All the chemicals were of analytical grade and were procured from Sigma Aldrich and Fluka. Metal salts were purchased from E. Merck and used as received.

Preparation of Complexes A hot ethanolic solution $(20 \mathrm{ml})$ of thiosemicarbazide $(1.8 \mathrm{~g}, 0.02 \mathrm{~mol})$ and a hot ethanolic solution $(20 \mathrm{ml})$ of the corresponding metal salt $(0.01 \mathrm{~mol})$ were refluxed for $3-4 \mathrm{~h}$ at $60^{\circ} \mathrm{C}$. On cooling colored complexes were precipitated out. They were filtered off, washed with $50 \%$ ethanol, and dried under vaccum over $\mathrm{P}_{4} \mathrm{O}_{10}$.

$\left[\mathrm{Ni}(\mathrm{L})_{2} \mathrm{Cl}_{2}\right]$ : Green powder. Yield 59\%. mp $300^{\circ} \mathrm{C}$. MS $m / z: 314\left(\mathrm{M}^{+}\right)$. Anal. Calcd for $\mathrm{C}_{2} \mathrm{H}_{10} \mathrm{~N}_{6} \mathrm{~S}_{2} \mathrm{Cl}_{2} \mathrm{Ni}$ : C, 7.70; H, 3.21, N, 26.94; Ni, 18.84 . Found: C, 7.54; H, 3.16; N, 26.71; Ni, 18.61 .

$\left[\mathrm{Ni}(\mathrm{L})_{2}\left(\mathrm{NO}_{3}\right)_{2}\right]$ : Brown powder. Yield $55 \%$. mp $240{ }^{\circ} \mathrm{C}$. MS m/z: 364 $\left(\mathrm{M}^{+}\right)$. Anal. Calcd for $\mathrm{C}_{2} \mathrm{H}_{10} \mathrm{~N}_{8} \mathrm{~S}_{2} \mathrm{O}_{6} \mathrm{Ni}$ : C, 6.58; H, 2.73; N, 23.01; Ni, 16.08. Found: C, $6.53 ; \mathrm{H}, 2.95 ; \mathrm{N}, 23.17 ; \mathrm{Ni}, 16.23$

$\left[\mathrm{Ni}(\mathrm{L})_{2}\left(\mathrm{CH}_{3} \mathrm{COO}\right)_{2}\right]$ : Brown powder. Yield $60 \%$. mp $190^{\circ} \mathrm{C}$. MS $m / z: 361$ $\left(\mathrm{M}^{+}\right)$. Anal. Calcd for $\mathrm{C}_{6} \mathrm{H}_{16} \mathrm{~N}_{6} \mathrm{~S}_{2} \mathrm{O}_{4} \mathrm{Ni} ; \mathrm{C}, 20.07 ; \mathrm{H}, 4.45 ; \mathrm{N}, 23.39$; Ni, 16.35. Found: C, 20.34; H, 4.09; N, 23.52; Ni, 16.49 .

$\left[\mathrm{Cu}(\mathrm{L})_{2} \mathrm{Cl}_{2}\right]$ : Brown powder. Yield $57 \%$. mp $190^{\circ} \mathrm{C}$. MS m/z: $315\left(\mathrm{M}^{+}\right)$. Anal. Calcd for $\mathrm{C}_{2} \mathrm{H}_{10} \mathrm{~N}_{6} \mathrm{~S}_{2} \mathrm{Cl}_{2} \mathrm{Cu}$ : C, 7.59; H, 3.16; N, 26.55; Cu, 20.08. Found: C, 7.36; H, 3.03; N, 26.76; Cu, 20.32.

$\left[\mathrm{Cu}(\mathrm{L})_{2}\left(\mathrm{NO}_{3}\right)_{2}\right]$ : Brown powder. Yield $61 \%$. mp $>350^{\circ} \mathrm{C}$. MS m/z: 372 $\left(\mathrm{M}^{+}\right)$. Anal. Calcd for $\mathrm{C}_{2} \mathrm{H}_{10} \mathrm{~N}_{8} \mathrm{~S}_{2} \mathrm{O}_{6} \mathrm{Cu}: \mathrm{C}, 6.49 ; \mathrm{H}, 2.70 ; \mathrm{N}, 22.71 ; \mathrm{Cu}$, 17.18. Found: $\mathrm{C}, 6.52 ; \mathrm{H}, 2.79 ; \mathrm{N}, 22.92 ; \mathrm{Cu}, 17.02$

$\left[\mathrm{Cu}(\mathrm{L})_{2}\left(\mathrm{CH}_{3} \mathrm{COO}\right)_{2}\right]$ : Brown powder. Yield $55 \%$. mp $180^{\circ} \mathrm{C}$. MS $\mathrm{m} / \mathrm{z}$ : 365 $\left(\mathrm{M}^{+}\right)$. Anal. Calcd for $\mathrm{C}_{6} \mathrm{H}_{16} \mathrm{~N}_{6} \mathrm{~S}_{2} \mathrm{O}_{4} \mathrm{Cu} ; \mathrm{C}, 6.60 ; \mathrm{H}, 2.74 ; \mathrm{N}, 23.08 ; \mathrm{Cu}$, 17.46. Found: C, 6.49; H, 2.92; N, 23.15, Cu, 17.33.

Antimicrobial Screening In vitro antimicrobial screening was performed by the agar disc diffusion method. ${ }^{23,24)}$ All the test organisms were obtained from Microbial Type Culture Collection and Gene Bank (MTCC) (Institute of Microbial Technology, Chandigarh, India). Nutrient agar growth media was prepared according to the instructions of MTCC. Twenty-five milliliter nutrient agar media was poured in each petriplate of $90 \mathrm{~mm}$ diameter. The inoculum was spread on the top of solidified media. Sterile discs of Whatman No. 1 filter paper having a diameter of $6 \mathrm{~mm}$, impregnated with the test compounds were placed at four equidistant places on the inoculated petriplates. The zone of inhibition was calculated in millimeters.

The antibacterial activity of thiosemicarbazide and its metal complexes were tested against Gram-positive (Staphylococcus aureus and Staphylococcus epidermides) and Gram-negative (Escherichia coli and Pseudomonas aeruginosa) pathogenic bacteria at a concentration of $100 \mu \mathrm{g} \mathrm{disc}^{-1}$. Nutrient agar media was prepared by using peptone, beef extract, yeast extract, $\mathrm{NaCl}$, agar-agar, and distilled water. Bacterial cultures were adjusted to 0.5 McFarland turbidity standard and inoculated onto the nutrient agar plates. $\left.{ }^{25}\right)$ The discs were carefully transferred onto the seeded agar plates. Filter paper 
disc treated with DMSO served as control and Amikacin $\left(30 \mu \mathrm{g} \operatorname{disc}^{-1}\right)$ was used as a standard drug. All determinations were made in duplicate for each of the compounds. An average of two independent readings for each compound was recorded. The petriplates were incubated at $37^{\circ} \mathrm{C}$ for $24 \mathrm{~h}$. The zone of inhibition was calculated.

The antifungal activity of thiosemicarbazide and its metal complexes was tested against two pathogenic fungi, Candida albicans and Aspergillus niger at a concentration of $200 \mu \mathrm{g} \mathrm{disc}^{-1}$ for each. Nystatin $\left(200 \mu \mathrm{g} \mathrm{disc}^{-1}\right)$ was used as standard fungicide and DMSO served as a means of control. For Candida albicans nutrient agar media was prepared using yeast extract, peptone dextrose, agar-agar and distilled water. Inoculum suspension in normal saline was prepared from fresh, mature ( $3-5 \mathrm{~d}$ old) cultures grown on nutrient agar slants. Using spectrophotometry at $530 \mathrm{~nm}$, turbidity was measured and adjusted to match a 0.5 McFarland density standard resulting in an inoculum containing $1 \times 10^{6}$ to $5 \times 10^{6}$ fungal cells $/ \mathrm{ml}^{26}{ }^{26}$ This suspension was used to directly inoculate agar plates.

For Aspergillus niger, nutrient agar media was prepared using czapek concentrate $\left(\mathrm{NaNO}_{3}, \mathrm{KCl}, \mathrm{MgSO}_{4} \cdot 7 \mathrm{H}_{2} \mathrm{O}, \mathrm{FeSO}_{4} \cdot 7 \mathrm{H}_{2} \mathrm{O}\right.$, and distilled water $)$, $\mathrm{K}_{2} \mathrm{HPO}_{4}$, yeast extract, sucrose, agar-agar and distilled water. Seven days old colonies were covered with approximately $1 \mathrm{ml}$ of sterile $0.85 \%$ saline and the suspensions were made by gently probing the colonies. The resulting mixture of conidia and hyphal fragments was withdrawn and transferred to sterile tube. After heavy particles were allowed to settle for $3-5 \mathrm{~min}$, the upper homogenous suspensions were collected. The densities of the conidial suspensions were read and adjusted to an optical density (OD) that ranged from $0.09-0.11$ ( 80 to $82 \%$ transmittance) at $\left.530 \mathrm{~nm} .{ }^{27}\right)$ The sterile discs impregnated with the test compounds were placed on the already seeded plates at $30^{\circ} \mathrm{C}$ for $48 \mathrm{~h}$. A clearing zone around the disc indicated the inhibition activity of the test compounds on the pathogenic fungi.

\section{Results and Discussion}

The complexes were synthesized by reacting thiosemicarbazide with the metal ions in $2: 1$ molar ratio in an ethanolic medium. Thiosemicarbazide behaves as bidentate and coordinates through the terminal amino $\mathrm{N}$ and $\mathrm{S}$ atoms. The analytical data, magnetic susceptibility, and spectral analysis agree well with the proposed composition of $\mathrm{Ni}(\mathrm{II})$ and $\mathrm{Cu}$ (II) complexes of thiosemicarbazide. The molar conductance of the complexes in $N, N$-dimethylformamide (DMF) lies in the range of $10-20 \Omega^{-1} \mathrm{~cm}^{2} \mathrm{~mol}^{-1}$ indicating their nonelectrolyte behaviour. Thus, the complexes may be formulated as $\left[\mathrm{M}(\mathrm{L})_{2} \mathrm{X}_{2}\right]$, (where $\mathrm{M}=\mathrm{Ni}$ (II) and $\mathrm{Cu}(\mathrm{II})$; $\mathrm{L}=$ thiosemicarbazide; $\mathrm{X}=\mathrm{Cl}^{-}, \mathrm{NO}_{3}^{-}$and $\mathrm{CH}_{3} \mathrm{COO}^{-}$). Complexes containing $\mathrm{Cl}^{-}$and $\mathrm{CH}_{3} \mathrm{COO}^{-}$are produced in trans form while cis form is obtained when $\mathrm{NO}_{3}^{-}$is the anion as shown in Figs. 1A, B.

Magnetic Susceptibility As shown in the Table 2, magnetic moment observed for the $\mathrm{Ni}$ (II) complexes lies in the range of $2.91-2.95 \mathrm{BM}$ which is consistent with the octahedral stereochemistry of the complexes while the room temperature magnetic moment of the $\mathrm{Cu}(\mathrm{II})$ complexes lies in the range $1.77-1.83 \mathrm{BM}$, corresponding to one unpaired electron.

IR Spectra The assignments of the significant IR spec- tral bands of thiosemicarbazide and its metal complexes are presented in Table 1 . The $3365 \mathrm{~cm}^{-1}$ band in thiosemicarbazide due to $v_{\text {as }}\left(\mathrm{NH}_{2}\right)$ is shifted to lower frequencies in the complexes. Thiosemicarbazide has two bands at 1642 and $1619 \mathrm{~cm}^{-1}$. The former is the deformation mode, $\delta\left(\mathrm{NH}_{2}\right)$, of the amine in the hydrazine residue, and the latter is the amide (II) band of primary amine. These bands shift towards lower frequencies due to the involvement of one of the $\mathrm{NH}_{2}$ group in coordination. Strong evidence is the appearance of the $430-459 \mathrm{~cm}^{-1}$ band due to $v(\mathrm{M}-\mathrm{N})$. Strong band at $800 \mathrm{~cm}^{-1}$ assigned to $\mathrm{C}=\mathrm{S}$ stretching vibration shifts to lower frequencies in the complexes, indicating the involvement of thioketo sulfur in complex formation. In each complex, two thiosemicarbazide ligands coordinate to the central metal ion through two terminal hydrazine $\mathrm{N}$ atoms and two $\mathrm{S}$ atoms. Thus, it is concluded that the ligand acts as bidentate chelating agent. The infrared spectra of trans and cis complexes show marked differences in certain regions of the spectrum. For the region around $3400-3000 \mathrm{~cm}^{-1}$, where $\mathrm{NH}_{2}$ stretching frequencies are observed, the trans isomers show two sharp strong bands. The corresponding cis isomers show only broad bands throughout this range. In the region around $1600 \mathrm{~cm}^{-1}$, corresponding to $\mathrm{NH}_{2}$ bending modes, two sharp bands are observed for the trans isomer, while a single broad band is observed for cis isomer. ${ }^{19)}$

The presence of bands at 1458-1412, 1320 - 1299 and $1056-1012 \mathrm{~cm}^{-1}$, in the IR spectra of metal complexes of $\mathrm{Ni}(\mathrm{II})$ and $\mathrm{Cu}(\mathrm{II})$, suggests that both the nitrate groups are coordinated to the central metal ion in a unidentate fashion. In the IR spectra of chloro complexes, bands corresponding to $v(\mathrm{M}-\mathrm{Cl})$ are observed at $345-320 \mathrm{~cm}^{-1}$ indicating the presence of $\mathrm{M}-\mathrm{Cl}$ bond. The IR spectra of $\mathrm{Ni}(\mathrm{II})$ and $\mathrm{Cu}$ (II) of acetato complexes show the medium intensity bands at 1620 and $1332-1320 \mathrm{~cm}^{-1}$, assigned to $v_{\mathrm{a}}(\mathrm{C}-\mathrm{O})$ and $v_{\mathrm{s}}(\mathrm{C}-\mathrm{O})$, respectively. The difference between these two frequencies is $c a .289 \mathrm{~cm}^{-1}$, which is greater than that for uncoordinated acetate ions by $c a .145 \mathrm{~cm}^{-1}$ and that for bidentate

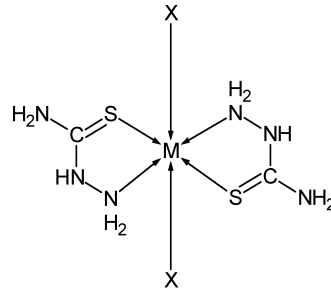

(A)

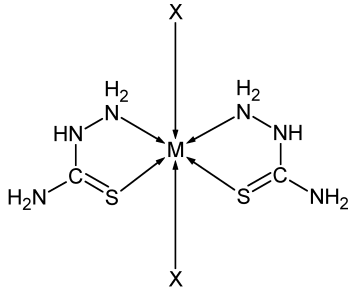

(B)
Fig. 1. Suggested Structure of the Complexes

(A) trans- $\left[\mathrm{M}(\mathrm{L})_{2} \mathrm{X}_{2}\right]$, where $\mathrm{M}=\mathrm{Ni}(\mathrm{II})$ and $\mathrm{Cu}(\mathrm{II})$ and $\mathrm{X}=\mathrm{Cl}^{-}$and $\mathrm{CH}_{3} \mathrm{COO}^{-}$. (B) cis- $\left[\mathrm{M}(\mathrm{L})_{2} \mathrm{X}_{2}\right]$, where $\mathrm{M}=\mathrm{Ni}(\mathrm{II})$ and $\mathrm{Cu}(\mathrm{II})$ and $\mathrm{X}=\mathrm{NO}_{3}^{-}$.

Table 1. Important IR Spectral Bands of Thiosemicarbazide and Its Complexes $\left(\mathrm{cm}^{-1}\right)$

\begin{tabular}{|c|c|c|c|c|c|c|}
\hline Compounds & $v_{\mathrm{as}}\left(\mathrm{NH}_{2}\right)$ & $v_{\mathrm{s}}\left(\mathrm{NH}_{2}\right)$ & $\delta\left(\mathrm{NH}_{2}\right)$ & $v(\mathrm{C}=\mathrm{S})$ & $v(\mathrm{M}-\mathrm{N})$ & $v(\mathrm{M}-\mathrm{S})$ \\
\hline $\mathrm{CH}_{5} \mathrm{~N}_{3} \mathrm{~S}(\mathrm{~L})$ & 3365 & 3263 & 1642 & 800 & - & - \\
\hline$\left[\mathrm{Ni}(\mathrm{L})_{2} \mathrm{Cl}_{2}\right]$ & 3349 & 3256 & 1638 & 703 & 436 & 330 \\
\hline$\left[\mathrm{Ni}(\mathrm{L})_{2}\left(\mathrm{NO}_{3}\right)_{2}\right]$ & 3317 & 3153 & 1633 & 697 & 431 & 317 \\
\hline$\left[\mathrm{Ni}(\mathrm{L})_{2}\left(\mathrm{CH}_{3} \mathrm{COO}\right)_{2}\right]$ & 3344 & 3176 & 1620 & 701 & 439 & 355 \\
\hline$\left[\mathrm{Cu}(\mathrm{L})_{2} \mathrm{Cl}_{2}\right]$ & 3338 & 3247 & 1633 & 784 & 430 & 330 \\
\hline$\left[\mathrm{Cu}(\mathrm{L})_{2}\left(\mathrm{NO}_{3}\right)_{2}\right]$ & 3320 & 3244 & 1635 & 779 & 452 & 346 \\
\hline$\left[\mathrm{Cu}(\mathrm{L})_{2}\left(\mathrm{CH}_{3} \mathrm{COO}\right)_{2}\right]$ & 3302 & 3243 & 1632 & 708 & 459 & 361 \\
\hline
\end{tabular}


Table 2. Electronic, EPR Spectral Data and Magnetic Moment for Thiosemicarbazide Complexes

\begin{tabular}{|c|c|c|c|c|c|c|}
\hline Complexes & $\lambda_{\max }\left(\mathrm{cm}^{-1}\right)$ & $g_{\|}$ & $g_{\perp}$ & $g_{\text {iso }}$ & $G$ & $\mu_{\text {eff }} \mathrm{BM}$ \\
\hline$\left[\mathrm{Ni}(\mathrm{L})_{2} \mathrm{Cl}_{2}\right]$ & $9337,14124,24100$ & - & - & - & - & 2.92 \\
\hline$\left[\mathrm{Ni}(\mathrm{L})_{2}\left(\mathrm{NO}_{3}\right)_{2}\right]$ & $9765,14350,24200$ & - & - & - & - & 2.91 \\
\hline$\left[\mathrm{Ni}(\mathrm{L})_{2}\left(\mathrm{CH}_{3} \mathrm{COO}\right)_{2}\right]$ & $9870,14577,25700$ & - & - & - & - & 2.95 \\
\hline$\left[\mathrm{Cu}(\mathrm{L})_{2} \mathrm{Cl}_{2}\right]$ & $14562,20190,23903$ & 2.27 & 2.08 & 2.14 & 3.37 & 1.77 \\
\hline$\left[\mathrm{Cu}(\mathrm{L})_{2}\left(\mathrm{NO}_{3}\right)_{2}\right]$ & $14800,20480,24180$ & 2.13 & 2.05 & 2.07 & 2.60 & 1.80 \\
\hline$\left[\mathrm{Cu}(\mathrm{L})_{2}\left(\mathrm{CH}_{3} \mathrm{COO}\right)_{2}\right]$ & $15625,21048,24248$ & 2.24 & 2.07 & 2.12 & 3.42 & 1.83 \\
\hline
\end{tabular}

Table 3. Antibacterial Activity of Thiosemicarbazide and Its Complexes

\begin{tabular}{|c|c|c|c|c|}
\hline \multirow{2}{*}{ Compounds } & \multicolumn{4}{|c|}{ Diameter of zone of inhibition (mm) } \\
\hline & Staphylococcus aureus & Staphylococcus epidermidis & Escherichia coli & Pseudomonas aeruginosa \\
\hline $\mathrm{CH}_{5} \mathrm{~N}_{3} \mathrm{~S}(\mathrm{~L})$ & - & - & - & - \\
\hline$\left[\mathrm{Ni}(\mathrm{L})_{2} \mathrm{Cl}_{2}\right]$ & - & - & - & - \\
\hline$\left[\mathrm{Ni}(\mathrm{L})_{2}\left(\mathrm{NO}_{3}\right)_{2}\right]$ & - & - & - & - \\
\hline$\left[\mathrm{Ni}(\mathrm{L})_{2}\left(\mathrm{CH}_{3} \mathrm{COO}\right)_{2}\right]$ & - & - & - & - \\
\hline$\left[\mathrm{Cu}(\mathrm{L})_{2} \mathrm{Cl}_{2}\right]$ & 12 & 12 & 11 & 10 \\
\hline$\left[\mathrm{Cu}(\mathrm{L})_{2}\left(\mathrm{NO}_{3}\right)_{2}\right]$ & 13 & 12 & 10 & 9 \\
\hline$\left[\mathrm{Cu}(\mathrm{L})_{2}\left(\mathrm{CH}_{3} \mathrm{COO}\right)_{2}\right]$ & 10 & 11 & 10 & 8 \\
\hline Amikacin & 26 & 22 & 21 & 20 \\
\hline
\end{tabular}

acetate ion by $c a .219 \mathrm{~cm}^{-1}$. It is strongly supported that both the acetate ions are coordinated to the metal ion in a unidentate fashion. ${ }^{28-30)}$

Electronic Spectra The electronic spectra of Nickel(II) complexes display three absorption bands (Table 2) in the range $9870-9337,14577-14124$ and $25700-24100 \mathrm{~cm}^{-1}$. The ground state of $\mathrm{Ni}(\mathrm{II})$ in an octahedral coordination is ${ }^{3} \mathrm{~A}_{2 \mathrm{~g}}$. Thus, these bands may be assigned to three spin-allowed transitions: ${ }^{3} \mathrm{~A}_{2 \mathrm{~g}}(\mathrm{~F}) \rightarrow{ }^{3} \mathrm{~T}_{2 \mathrm{~g}}(\mathrm{~F})\left(v_{1}\right),{ }^{3} \mathrm{~A}_{2 \mathrm{~g}}(\mathrm{~F}) \rightarrow{ }^{3} \mathrm{~T}_{1 \mathrm{~g}}(\mathrm{~F})$ $\left(v_{2}\right)$ and ${ }^{3} \mathrm{~A}_{2 \mathrm{~g}}(\mathrm{~F}) \rightarrow{ }^{3} \mathrm{~T}_{1 \mathrm{~g}}(\mathrm{P})\left(v_{3}\right)$, respectively. The position of the bands indicates that the $\mathrm{Ni}$ (II) complexes have six coordinate octahedral geometries. ${ }^{31)}$ The electronic spectra of six coordinated $\mathrm{Cu}$ (II) complexes display bands in the range 15625-14592, 21048-20190 and $24248-23903 \mathrm{~cm}^{-1}$ corresponding to following transitions: ${ }^{2} \mathrm{~B}_{1 \mathrm{~g}} \rightarrow{ }^{2} \mathrm{~A}_{1 \mathrm{~g}}\left(d_{x^{2}-y^{2}} \rightarrow\right.$ $\left.d_{z^{2}}\right) v_{1},{ }^{2} \mathrm{~B}_{1 \mathrm{~g}} \rightarrow{ }^{2} \mathrm{~B}_{2 \mathrm{~g}} \quad\left(d_{x^{2}-y^{2}} \rightarrow d_{z y}\right) v_{2}$ and ${ }^{2} \mathrm{~B}_{1 \mathrm{~g}} \rightarrow{ }^{2} \mathrm{E}_{\mathrm{g}} \quad\left(d_{x^{2}-y^{2}} \rightarrow\right.$ $\left.d_{z y} d_{y z}\right) v_{3}$, respectively. Therefore, the $\mathrm{Cu}(\mathrm{II})$ complex may be considered to possess a tetragonal geometry. ${ }^{32,33)}$

Electronic Paramagnetic Spectra Room temperature EPR spectra of $\mathrm{Cu}$ (II) complexes were recorded as polycrystalline sample, at frequency of $9.1 \mathrm{GHz}$ under the magnetic field strength of $3000 \mathrm{G}$. The analysis of spectra gives $g_{\|}=2.27-2.13, g_{\perp}=2.08-2.05$ as shown in Table 2 . The observed $g_{\|}$values for the complexes are less than 2.3 in agreement with the covalent character of the metal ligand bond. The trend $g_{\|}>g_{\perp}>2.0023$ observed for the complexes indicates that unpaired electron is localized in $d_{x^{2}-y^{2}}$ orbital of the $\mathrm{Cu}$ (II) ion and the spectral features are a characteristic of axial symmetry. Thus, a tetragonal geometry is confirmed for the aforesaid complexes. ${ }^{34)}$

$G=\left(g_{\|}-2\right) /\left(g_{\perp}-2\right)$, which measures the exchange interaction between the metal centres in a polycrystalline solid, has been calculated. According to Hathaway et al., ${ }^{35)}$ if $G>4$, the exchange interaction is negligible, but $G<4$ indicates considerable exchange interaction in solid complexes. The complexes reported in this paper give the ' $G$ ' value in the range $2.60-3.42$, which is $<4$, indicating the exchange interaction in the solid complexes.

Antimicrobial Activity The antimicrobial screening data shows that thiosemicarbazide does not exhibit antimicrobial activity. Ni(II) complexes did not inhibit the growth of test organisms. However, they were found to be active against Candida albicans. Our results are in agreement with the earlier findings that 6-coordinate, paramagnetic Ni(II) complexes with two ligands do not inhibit growth of test organisms. Thus, in the Ni(II) complexes, the antimicrobial activity against the test organisms can correlate with their ligand-replacement abilities rather than solubility or hydrophobicity of the complexes. ${ }^{4)}$ From the Table 3 , it is clear that $\mathrm{Cu}$ (II) metal chelates exhibit effective antibacterial activities. The increased activity of the metal chelate can be explained on the basis of chelation theory. It is known that chelation tends to make the ligand act as more powerful and potent bactericidal agent, killing more of the bacteria than the ligand. It is observed that in a complex the positive charge of the metal is partially shared with the donor atoms present in the ligands and there may be $\pi$-electron delocalization over the whole chelating. ${ }^{36)}$ This increases the lipophilic character of the metal chelate and favors its permeation through the lipoid layer of the bacterial membranes. There are other factors which also increase the activity, namely, solubility, conductivity, and bond length between the metal and ligand. The result of fungicidal screening as shown in Table 4 shows that $\mathrm{Cu}$ (II) complexes were active against pathogenic fungi, Candida albicans but showed no activity against Aspergillus niger.

The proposed study revealed an octahedral geometry in the $\mathrm{Ni}$ (II) complexes, whereas tetragonal geometry in $\mathrm{Cu}$ (II) complexes. Ligand acts as a bidentate chelating agent coordinating through the sulfur and terminal amino nitrogen atoms to form 5-membered chelate rings. The results of antimicrobial activity show that thiosemicarbazide itself does not exhibit antibacterial and antifungal activities. However it is important to note that $\mathrm{Cu}(\mathrm{II})$ complexes exhibited antimicrobial 
Table 4. Antifungal Activity of Thiosemicarbazide and Its Complexes

\begin{tabular}{lcc}
\hline \hline \multirow{2}{*}{ Compounds } & \multicolumn{2}{c}{ Diameter of zone of inhibition (mm) } \\
\cline { 2 - 3 } & Candida albicans & Aspergillus niger \\
\hline $\mathrm{CH}_{5} \mathrm{~N}_{3} \mathrm{~S}(\mathrm{~L})$ & - & - \\
{$\left[\mathrm{Ni}(\mathrm{L})_{2} \mathrm{Cl}_{2}\right]$} & 8 & - \\
{$\left[\mathrm{Ni}(\mathrm{L})_{2}\left(\mathrm{NO}_{3}\right)_{2}\right]$} & 8 & - \\
{$\left[\mathrm{Ni}(\mathrm{L})_{2}\left(\mathrm{CH}_{3} \mathrm{COO}\right)_{2}\right]$} & 8 & - \\
{$\left[\mathrm{Cu}(\mathrm{L})_{2} \mathrm{Cl}_{2}\right]$} & 14 & - \\
{$\left[\mathrm{Cu}(\mathrm{L})_{2}\left(\mathrm{NO}_{3}\right)_{2}\right]$} & 10 & - \\
{$\left[\mathrm{Cu}(\mathrm{L})_{2}\left(\mathrm{CH}_{3} \mathrm{COO}\right)_{2}\right]$} & 9 & 18 \\
$\mathrm{Nystatin}$ & 26 &
\end{tabular}

activities. $\mathrm{Cu}(\mathrm{II})$ complexes showed more activity than the $\mathrm{Ni}$ (II) complexes. This may be due to the higher stability of $\mathrm{Cu}$ (II) complexes than the other complexes. ${ }^{37)}$ It is interesting to know that 6-coordinate, paramagnetic Ni(II) complexes did not exhibit antibacterial activities. Their antifungal activities were also found to be much less compared to copper complexes. None of the complexes showed activity against Aspergillus niger.

Acknowledgements We are grateful to ITS Paramedical College (Pharmacy), for providing the research facilities and RSIC, IIT Mumbai, for recording EPR spectra.

\section{References}

1) Kasuga N. C., Sekino M., Koumo C., Shimada N., Ishikawa M., Nomiya K., J. Inorg. Biochem., 84, 55-65 (2001).

2) Chandra S., Gupta L. K., Spectrochim. Acta A, 62, 1089-1094 (2005).

3) Demertzi D. K., Demertzis M. A., Miller J. R., Papadopoulou C., Dodorou C., Filousis G., J. Inorg. Biochem., 86, 555-563 (2001).

4) Singh S., Athar F., Maurya M. R., Azam A., Eur. J. Med. Chem., 41, 592-598 (2006).

5) Easmon J., Purstinger G., Heinisch G., Roth T., Fiebig H. H., Holzer W., Jager W., Jenny M., Hofmann J., J. Med. Chem., 44, 2164-2171 (2001).

6) Seebacher W., Brun R., Weis R., Eur. J. Pharm. Sci., 21, 225-233 (2004).

7) Kolocouris A., Dimas K., Pannecouque C., Mitvrouw M., Foscolos G. B., Stamatiou G., Fytas G., Zoidis G., Kolocouris N., Andrei G., Snoeck R., Clereq E. D., Bioorg. Med. Chem. Lett., 12, 723-727 (2002).

8) Aguirre G., Boiani L., Cerecetto H., Fernández M., González M., Denicola A., Otero L., Gambino D., Rigol C., Olea-Azar C., Faundez M., Bioorg. Med. Chem., 12, 4885-4893 (2004).

9) Du X., Guo C., Hansell E., Doyle P. S., Caffrey C. R., Holler T. P.,
Mckerrow J. H., Cohen F. E., J. Med. Chem., 45, 2695-2707 (2002).

10) Du X., Hansell E., Engel J. C., Caffrey C. R., Cohen F. E., Mckerrow J. H., Chem. Biol., 7, 733-742 (2002).

11) Liu M. C., Lin T. S., Cory J. G., Cory A. H., J. Med. Chem., 39, $2586-2593$ (1996)

12) García-Tojal J., García-Orad A., Díaz A. A., Serra J. L., Urtiaga M. K., Arriortua M. I., Rojo T., J. Inorg. Biochem., 84, 271-278 (2001).

13) Bharti N., Athar F., Maurya M. R., Azam A., Bioorg. Med. Chem., 12, 4679-4684 (2004)

14) Jeragh B. J. A., El-Dissouky, J. Coord. Chem., 58, 1029-1038 (2005).

15) Labisbal E., Haslow K. D., Sousa-Pedrares A., Valdés-Martinez J., Hernández-Ortega S., West D. X., Polyhedron, 22, 2831-2837 (2003).

16) Castiñeiras A., Bermejo E., Valdez-Martínez J., Espinosa-Pérez G., West D. X., J. Mol. Chem., 522, 271-278 (2000).

17) Krishna P. M., Reddy K. H., Krishna P. G., Philip G. H., Indian J. Chem., 46A, 904-908 (2007).

18) Gonzalez A. D., Ortega S. H., Martínez J. V., Acta Cryst., E63, m1120-m1121 (2007).

19) Hanes R. A., Sun K. K. W., Can. J. Chem., 46, 3241-3247 (1968).

20) Koksharova T. V., Ukr. Khim. Zh., 55, 1244-1247 (1989).

21) Nardell M., Gazz. Chim. Ital., 91, 280-288 (1961).

22) Chattopadhyay D., Majumdar S. K., Lowe P., Schwalbe C. H., Chattopadhyay S. K., Ghosh S., J. Chem. Soc., Dalton Trans., 1991, 2121-2124 (1991).

23) Bauer A. W., Kirby W. M., Sherris J. C., Turck M., Am. J. Clin. Pathol., 45, 493-496 (1966).

24) Sheikh C., Hossain M. S., Easmin M. S., Islam M. S., Rashid M., Biol. Pharm. Bull., 27, 710-713 (2004).

25) Andrews J. M., J. Antimicrob. Chemother, 56, 60-76 (2005).

26) Sims C. R., Paetznick V. L., Rodriguez J. R., Chen E., Zeichner L. O., J. Clin. Microbiol., 44, 2105-2108 (2006)

27) Espinel-Ingroff A., Bartlett M., Bowden R., Chin N. X., Cooper C., Fothergill A., Mcginnis M. R., Menezes P., Messer S. A., Nelson P. W., Odds F. C., Pasarell L., Peter J., Pfaller M. A., Rex J. H., Rinaldi M. G., Shankland G. S., Walsh T. J., Weitzman I., J. Clin. Microbiol., 35, 139-143 (1997).

28) Bailey R. A., Kozak S. L., Michelson T. W., Mills W. N., Coord. Chem. Rev., 6, 407-445 (1971).

29) Hester R. E., Grossman W. E. L., Inorg. Chem., 5, 1308-1312 (1966).

30) Nakamoto K., "Infrared and Raman Spectra of Inorganic and Coordination Compounds," 3rd ed., John Wiley and Sons, New York, 1978.

31) Chandra S., Kumar U., J. Saudi. Chem. Soc., 11, 77-84 (2004).

32) Lever A. B. P., "Inorganic Electronic Spectroscopy," Amsterdam, 1984.

33) Chandra S., Gupta L. K., Spectrochim. Acta A, 60, 1751-1761 (2004).

34) Chandra S., Kumar U., Spectrochim. Acta A, 60, 2825-2829 (2004).

35) Hathaway B. J., Bardley J. N., Gillard R. D., "Essay in Chemistry," Academic Press, New York, 1971.

36) Sengupta S. K., Pandey O. P., Srivastava B. K., Sharma V. K., Trans. Met. Chem., 23, 349-352 (1998).

37) Chandra S., Gupta L. K., J. Ind. Chem. Soc., 81, 739-744 (2001). 